\title{
PERFORMING THE ACTIVITIES OF TRAVEL AGENCIES IN SERBIA DURING THE COVID 19 VIRUS PANDEMIC
}

Summary: This paper aims to show the extent to which travel agencies in Serbia are ready to operate in crises, such as the current one caused by the Covid 19 virus pandemic, and what consequences such a pandemic can have on the entire tourism industry of a country. To achieve these goals, data from various researches conducted during 2020 on the impact of the Covid 19 pandemic on the world tourism industry were used, as well as relevant statistical data from international organizations and state institutions of the Republic of Serbia. The paper concluded that travel agencies are highly dependent on state aid, but these resources are also limited. All solutions proposed by the Government of the Republic of Serbia are time-limited until the end of 2021 when there is hope that the virus will weaken, in which the planned vaccination of the population should play a major role. For travel agencies to be able to overcome situations such as the virus pandemic in the future, they need to work on new programs and adapt to new target groups and markets. New sales channels need to be opened, in case of some new crises, so that the agencies are ready and able to survive under the given circumstances.

Keywords: travel agencies, Covid 19, crisis, tourism.

Faculty of Hotel Management and Tourism in Vrnjačka Banja, University of Kragujevac, Serbia; racapn@gmail.com

** Faculty of Sciences Nis, Serbia; krsticmilo3@gmail.com

** Faculty of Hotel Management and Tourism in Vrnjačka Banja, University of Kragujevac, Serbia; marija.lakicevic@kg.ac.rs 


\section{Introduction}

The tourism industry represents a significant part of the global economy. However, tourism demand is very sensitive to crisis events, such as economic crises, epidemics, pandemics, natural disasters and terrorist attacks. ${ }^{1}$ The tourism sector was hardest hit by the outbreak of the Covid 19 pandemic and suffered heavy financial losses. At this moment (end of December 2020), there are still no indications when recovery could occur. According to the UNWTO, the losses incurred are up to five times higher than those caused by the global financial crisis more than ten years ago. The same situation affected the tourism sector in the Republic of Serbia. The loss in 2020 is estimated to be more than a billion euros. A large number of people who were employed in tourism lost their jobs, some companies stopped working. During March and April 2020, the Serbian government invested some limited resources to support the sector, hoping that the coronavirus would lose intensity during the summer and that the economy, including tourism, would continue to function normally, but the coronavirus expansion exceeded all expectations. Problems remain, and the pandemic is not over, although the process of vaccination of the population has been initiated in many countries, including Serbia.

The pandemic affected travel agencies, both those dealing with receptive tourism and agencies dealing with the organization of travel arrangements abroad, mostly in the summer and winter months, during vacations and holidays. The paper presents the problems that travel agencies encountered in Serbia in 2020 caused by the corona virus pandemic of the official name Covid 19, the consequences felt by the domestic economy and the tourism sector itself, as well as proposals and concrete solutions presented at the end of 2020 by the Government of the Republic of Serbia and several associations of travel agencies in order to protect the tourism sector and preserve jobs. All the proposed solutions are time-limited until the end of 2021 when there is hope that the virus will weaken, in which the planned vaccination of the population should play a big role.

\section{The global impact of the Covid 19 pandemic on the tourism industry}

At the beginning of 2020, the Covid 19 pandemic appeared among the residents of Europe. The pandemic can be seen as a potential "game-changer" in tourism and travel ${ }^{2,3}$. The tourism industry, especially internationally, has diffi-

1 Luković, S., Stojković, D. (2020): Covid - 19 pandemic and global tourism, Hotel and Tourism Management 8 (2): 79 -87.

2 Hall, C.M., Scott, D., and Gössling, S. (2020): Pandemics, Transformations and Tourism: Be Careful What You Wish for. Tourism Geographies, first published 28 April, Available at: https://doi.org/10.1080/14616688.2020.1759131 (Accessed on 24.12.2020).

3 Gössling, S., Hall, C.M., and Scott, D., (2020): Pandemics, Tourism and Global Change: a Rapid Assessment of COVID-19. Journal of Sustainable Tourism, first published 27 April, 
culty coping with crises or disasters, as it poses a potential risk to the health and safety of tourists ${ }^{4}$ (Estevão \& Costa, 2020). According to the data of the World Health Organization (WHO) $)^{5}$, as of January 2, 2021, 84,944,864 people were infected with the Covid 19 virus in the world, of which 1,842,771 people have died. Tourism depends on how much freedom people have to travel from one place to another, and when a situation such as a virus pandemic occurs, then those trips are made much more difficult or people stop traveling altogether. There are numerous reasons for that, from closing borders, quarantine in countries, banning flights to airline companies, banning sailing on tourist ships and docking in ports, banning or restricting any gatherings, closing hotels, restaurants, bars. Another reason is the fear of infection and concern for one's health, due to the growing number of cases of people infected with the Covid 19 virus.

According to Matiza ${ }^{6}$, the world tourism industry has faced various challenges, which are reflected on the one hand in tourist demand (health, social and psychological risk is present), and on the other hand in the tourist offer (closing down many companies in the tourism sector, job losses, significantly increased fiscal deficit).

According to the United Nations World Tourism Organization ${ }^{7}$, international tourism could experience a decline of as much as $80 \%$ by the end of 2020 (the last report in January-October was $72 \%$ ), which would mean a decline in tourist arrivals by more than one billion by the end of 2020 (and according to confirmed data in January-October, the number has already reached 935 million fewer tourists compared to 2019). Over 100 million jobs in the tourism industry are at risk, including air transport, the transport sector, and catering.

The pandemic of the Covid 19 virus (better known as the corona virus) has caused significant economic, social, and societal disturbances globally ${ }^{8}$. The world economy has been forced to make rapid changes and adapt to the condi-

Available at: https://doi.org/10.1080/09669582.2020.1758708 (Accessed on 24.12.2020).

4 Estevão, C., and Costa, C. (2020): Natural disaster management in tourist destinations: a systematic literature review. European Journal of Tourism Research, 25, 2502, Available at: https://ejtr.vumk.eu/index.php/about/article/view/417 (Accessed on 29.12.2020.).

5 WHO Coronavirus Disease (COVID-19) Dashboard, Available at: https://covid19.who.int/ (Accessed on 02.01.2021).

6 Matiza, T. (2020): Post-COVID-19 crisis travel behaviour: towards mitigating the effects of perceived risk. Journal of Tourism Futures.

Available at: https://doi.org/10.1108/JTF-04-2020-0063 (Accessed on 24.12.2020).

7 UNWTO. (2020a). Impact assessment of the COVID-19 outbreak on international tourism, Updated December 2020.

Available at: https://www.unwto.org/impact-assessment-of-the-covid-19-outbreak-oninternational-tourism (Accessed on 24.12.2020)

8 Sumner, A., Hoy, C. and Ortiz-Juarez, E. (2020): Estimates of the impact of COVID-19 on global poverty. WIDER Working Paper 2020/43. UNU-WIDER, Available at: https://doi. org/10.35188/UNU-WIDER/2020/800-9 (Accessed on 29.12.2020). 
tions caused by the Covid 19 virus pandemic, and this situation has not escaped any sector, from international trade, finance, manufacturing, and services ${ }^{9}$.

The nature of the tourism industry is such that the consequences of the Covid 19 pandemic can be seen in all tourism activities ${ }^{10}$. Covid 19 has irreversibly caused changes in the world economy that have manifested themselves strongly in the tourism sector, acting very negatively on tourist demands and international travel, especially due to limited movement of people and quarantine in certain countries ${ }^{11}$.

Besides, this crisis has been felt most in the hospitality industry, which employs a large number of workers globally and is significantly vulnerable to any market shocks, such as the outbreak of a global virus pandemic ${ }^{12}$.

McKinsey published a blog in mid-April 2020 entitled "The future is not what it used to be: Thoughts on the shape of the next normal"13. The governments of the most powerful EU countries, large tourist operators, and airlines are aware of the fact that tourist travel is moving into a completely new way of doing business and organizing, but no one can say for sure what it will look like. Everyone firmly believes that everything will return to normal very soon and will do everything to make the tourist economy recover and to continue traveling as soon as adequate conditions are met. But the Covid 19 pandemic has left deep traces in all aspects of the economy, so to think that "everything will be the same again" would be unusual and unrealistic, to say the least. The experience of the tourism industry with the Covid 19 virus pandemic should be fully exploited, even when the pandemic is one day completely brought under control, to create a tourism sector that will be more resilient to the various crises in the future. "The Covid 19 pandemic needs to rethink the global model of tourism

$9 \quad$ Ma, C., Rogers, J. H. and Zhou, S. (2020): Modern Pandemics: Recession and Recovery (June 2020).

Available at SSRN: https://ssrn.com/abstract=3565646 or http://dx.doi.org/10.2139/ ssrn.3565646 (Accessed on 28.12.2020).

10 Chinazzi, M., Davis, J. T., Ajelli, M., Gioannini, C., Litvinova, M., Merler, S., ... and Viboud, C. (2020): The effect of travel restrictions on the spread of the 2019 novel coronavirus (COVID-19) outbreak. Science, 368(6489), 395-400, Available at: https://doi.org/10.1126/ science.aba9757 (Accessed on 26.12.2020).

11 Hoque, A., Shikha, F. A., Hasanat, M. W., Arif, I. and Hamid, A. B. A. (2020): The effect of Coronavirus (COVID-19) in the tourism industry in China. Asian Journal of Multidisciplinary Studies, 3(1), 52-58. (Accessed on 26.12.2020).

12 Chang, C.L., McAleer, M. and Ramos, V. (2020): A Charter for Sustainable Tourism after COVID-19, Sustainability, 12(9), 3671 Available at: https://doi.org/10.3390/su12093671 (Accessed on 26.12.2020).

13 McKinsey and Company. (2020): The future is not what it used to be: Thoughts on the shape of the next normal, Available at: https://www.mckinsey.com/featured-insights/leadership/the-future-is-not-what-it-used-to-be-thoughts-on-the-shape-of-the-next-normal\# (Accessed on 23.12.2020) 
growth, due to the many interrelated risks of travel organization globally, but also to the contribution of the tourism sector to climate change"14.

Even if they had the freedom to travel wherever they wanted, tourists could hardly avoid regions and destinations that were not affected by the corona virus, since the virus has affected practically the entire world. Because of this global expansion, Covid 19 differs from all the crises and phenomena seen so far that have befallen the tourism sector ${ }^{15}$.

The Covid 19 virus pandemic and the economic changes it has caused in the tourism industry of many countries around the world affected by it have become the subject of numerous studies ${ }^{16}, 17,18,19,20$, but what is certain is that no one can yet draw concrete conclusions and make assessments in which direction the whole situation may develop in the future. Also, based on some of these researches, there is no further intention to observe the travels of future tourists after the end of the pandemic.

At the very end of 2020, some pharmaceutical companies from the United States and Germany, but also from Russia, China, and Great Britain, after several months of research, offered a vaccine against the corona virus, which the governments of some countries, including Serbia, began to use, vaccinating primarily the most vulnerable and oldest members of their population, health workers working in the Covid system and the chronically ill. The effectiveness of these vaccines will be shown in the coming months. Pharmaceutical giants have their own busi-

14 Gössling, S., Hall, C.M. and Scott, D., (2020): Pandemics, Tourism and Global Change: a Rapid Assessment of COVID-19. Journal of Sustainable Tourism, first published 27 April, Available at: https://doi.org/10.1080/09669582.2020.1758708 (Accessed on 24.12.2020).

15 UNWTO. (2020b): Covid 19 Related Travel Restrictions, a Global Review for Tourism, First Report as of 16 April 2020. Madrid.

16 Brouder, P., Teoh, S., Salazar, N. B., Mostafanezhad, M., Pung, J. M., Lapointe, D., ... and Clausen, H. B. (2020): Reflections and discussions: tourism matters in the new normal post COVID-19. Tourism Geographies, 1-12, Available at: https://doi.org/10.1080/14616688 .2020.1770325 (Accessed on 24.12.2020).

17 Zenker, S. and Kock, F. (2020): The coronavirus pandemic-A critical discussion of a tourism research agenda. Tourism Management, 81, 104164. Available at: https://doi. org/10.1016/j.tourman.2020.104164 (Accessed on 24.12.2020).

18 Jamal, T. and Budke, C. (2020): Tourism in a world with pandemics: local-global responsibility and action. Journal of Tourism Futures, 6(2), 181-188, Available at: https://doi. org/10.1108/JTF-02-2020-0014 (Accessed on 24.12.2020).

19 Yang, Y., Zhang, H. and Chen, X. (2020): Coronavirus pandemic and tourism: Dynamic stochastic general equilibrium modeling of infectious disease outbreak. Annals of Tourism Research, 83, 102913 Available at: https://doi.org/10.1016/j.annals.2020.102913 (Accessed on 24.12.2020).

20 Abu Bakar, N. and Rosbi, S. (2020): Effect of coronavirus disease (COVID-19) to tourism industry. International Journal of Advanced Engineering Research and Science (IJAERS). 2020; 7(4). Available at: https://dx.doi.org/10.22161/ijaers.74.23, ISSN: 23496,189. (Accessed on 23.12.2020) 
ness and especially financial interests which, as a rule, transcend the borders of states, because in the modern world they are globalized by their nature. ${ }^{21}$ The Covid 19 virus pandemic showed "how sensitive humans are, and how their plans can be disrupted in a short time without them being able to react in the right way and on time"22. What is already certain is that the tourism industry will have a long and difficult recovery from the crisis caused by the pandemic ${ }^{23}$.

\section{The tourism sector in Serbia before coronavirus}

Serbia has not yet managed to use even half of its tourist potentials, although it has a good geographical position, beautiful nature and is well connected with the countries of the region, as well as with leading European countries, but also with major world countries such as the USA, Russia, and China. Unfavourable circumstances for the tourist sector in Serbia were: bad political situation, wars and the period of economic sanctions during 1990s.There is also a period of political changes that has accompanied the world, caused by the great World Economic Crisis of 2008, which did not bypass Serbia either. Since then, in the last few years a great progress has been made in the tourist industry. However with the occurrence of Covid 19 a greater decline has occurred in this important branch of the economy, than in 2008.

Since 2014, the tourism sector in Serbia has been in full swing, although that season did not show any promise due to unfavorable weather conditions, the results improved from year to year, there was an expansive growth of the tourism sector, as earnings from tourism were increasing. The tourism sector in Serbia contributed to GDP with $0.8 \%$ in 2001, and in 2018 that percentage was $2.4 \%$. During 2019, the growth of total guest arrivals and overnight stays was $7 \%$. In 2019, 1.4 billion euros of tourism revenue was generated compared to 1.2 billion a year earlier ${ }^{24}$. All predictions were that 2020 will be the best year for the tourism sector in Serbia since 1989, as evidenced by data for January and February 2020, when the number of tourist arrivals increased by $21 \%$, and the number of overnight stays by $22 \%$. The largest visit to Serbia was brought by tourists from the surrounding countries, but there was also an increase in the number of arrivals from Turkey, Greece, as well as more distant countries such

${ }_{21} \quad$ Rabrenović, Mihajlo, Stošić, Sanja i Stamenović, Milorad. (2016): Značaj strategijskog upravljanja za klinička ispitivanja. Pravni život.

22 Antonio, S. (2020): The Tourism Industry and the Impact of COVID 19: Scenario and Prospects, Global Journey Consulting, 2020.

23 Nepal, S. K., (2020): Travel and tourism after COVID-19 - business as usual or opportunity to reset? Tourism Geographies, 1470-1340. Available at: https://doi.org/10.1080/146166 88.2020.1760926 (Accessed on 24.12.2020).

24 Statistical Office of the Republic of Serbia (2020): Trends - III quarter 2020, Available at: https://publikacije.stat.gov.rs/G2020/pdf/G20208005.pdf (Accessed on 23.12.2020) 
as Russia, China, and the United States. In March 2020, as a consequence of the Covid 19 virus pandemic, there was a complete decline in the tourism industry in Serbia in all industries, starting with the state of emergency imposed in the country, which led to flight bans, interruption of international and intercity bus traffic, closing of borders, cancellation of tourist arrangements both in domestic hotels and contracted arrangements of foreign tourist destinations, in the first place in countries that are favorite vacation destinations of Serbian tourists, such as Greece, Montenegro, Spain, while some countries during the summer tourist season were open to Serbian citizens such as Croatia, Albania, Bosnia and Herzegovina, and even more distant Turkey and Egypt.

\section{Business indicators of the tourism sector in 2020 in Serbia}

In the period January - September 2020, 5.1 million overnight stays were registered, which was $36 \%$ less than in the same period the year before. The most significant year-on-year decline (94.6\%) was registered in April according to the Statistical Office of the Republic of Serbia ${ }^{25}$, while in later months a slightly higher number of overnight stays was realized, but still significantly lower than in the same period a year earlier (in July, August, and September a year-on-year decline of $35,9 \%, 17.1 \%$, and $22.9 \%$ in a row).

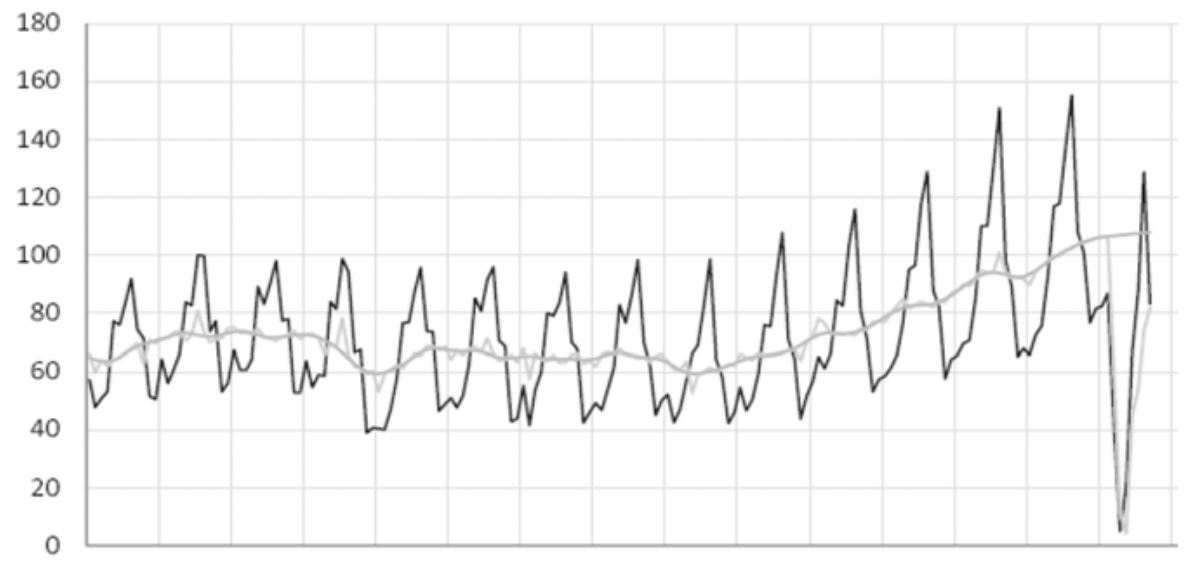

2006200720082009201020112012201320142015201620172018201920202021

Source: Statistical Office of the Republic of Serbia (2020), Trends - III quarter 2020.

Figure 1. Components of the time series of total tourist nights, indices

$(y$ - original series, sa - series with an excluded seasonal component, $t$ - trendcycle component, average $2019=100$ )

25 Ibid.

Vol. 18, № 1, 2021: 159-176 
According to the Statistical Office of the Republic of Serbia ${ }^{26}$, in the period from January to September 2020, domestic tourists realized 4.1 million overnight stays, which is $16 \%$ less overnight stays than in the same period the year before. This group of tourists represents the majority of visitors in Serbia, ie. $80.8 \%$ of the total number of nights. It was expected that the tourist activity would mostly rely on domestic tourists, due to the closure of borders and the ban on flights. In the third quarter of 2020, the number of domestic tourists was $13 \%$ higher than in the same period in 2019. On the other hand, the visit of foreign tourists, which has grown from year to year in the last 20 years, did not continue in 2020 due to the corona virus pandemic. In the first nine months of 2020, foreign tourists realized almost 980 thousand overnight stays, which was almost $70 \%$ less than in the same period in 2019.

Table 1. Tourist nights, quarterly indices (\%) (comparison with the same period the year before)

\begin{tabular}{|l|c|c|c|c|c|c|c|c|c|c|c|}
\cline { 2 - 12 } \multicolumn{1}{c|}{} & \multicolumn{4}{c|}{2018} & \multicolumn{4}{c|}{2019} & \multicolumn{3}{c|}{2020} \\
\cline { 2 - 12 } \multicolumn{1}{c|}{} & $\mathrm{Q} 1$ & $\mathrm{Q} 2$ & $\mathrm{Q} 3$ & $\mathrm{Q} 4$ & $\mathrm{Q} 1$ & $\mathrm{Q} 2$ & $\mathrm{Q} 3$ & $\mathrm{Q} 4$ & $\mathrm{Q} 1$ & $\mathrm{Q} 2$ & $\mathrm{Q} 3$ \\
\hline Total & 110,7 & 113,9 & 113,4 & 109,1 & 103,9 & 107,2 & 105,6 & 116,6 & 98,3 & 28,1 & 74,9 \\
\hline $\begin{array}{l}\text { Domestic } \\
\text { tourists }\end{array}$ & 109,2 & 113,6 & 110,2 & 106,7 & 101,3 & 107,6 & 105,4 & 113,6 & 101,5 & 39,3 & 113,0 \\
\hline $\begin{array}{l}\text { Foreign } \\
\text { tourists }\end{array}$ & 113,5 & 114,5 & 118,6 & 112,3 & 108,3 & 106,4 & 105,8 & 120,6 & 93,2 & 8,9 & 17,9 \\
\hline
\end{tabular}

Source: Statistical Office of the Republic of Serbia (2020), Trends - III quarter 2020.

The worst was the second quarter of 2020, due to the state of emergency that was in force in the country from March to June 2020. During that period, the decline in foreign tourist visits was $91 \%$ less than in 2019, and that percentage decreased slightly to $82 \%$ in the third quarter, when foreign tourist visits rose to slightly more than 241 thousands of tourists.

\section{Effects of the corona virus on the business of travel agencies in Serbia}

The sequence of events in the tourism sector of Serbia coincides with the rest of the world. The Serbian government declared an epidemic in early March, while a state of emergency was imposed in the country in the middle of the same month. These decisions in the tourism sector have triggered a mass cancellations of tourist arrivals of foreign tourists, as well as many domestic tourists. All student excursions in the country and abroad have also been cancelled. Travel agencies faced a situation of complete job loss and were about to close. Besides, the catering sector was hit due to the ban on the operation of the cafes and restau-

26 Ibid. 
rants and the limited gathering of people indoors. In the period from March to July 2020, as the intensity of the virus weakened and as the measures prescribed by the Government weakened, the number of domestic tourists increased, as the borders for Serbian citizens were still closed to Greece and Montenegro, the most common and the most visited destinations of Serbian tourists during the summer months and vacations. That is why a large number of domestic tourists decided to spend their vacation in spas and in the mountains in Serbia. However, the purchasing power of domestic tourists is not enough to cover the losses caused by the interruption of business in early March. Travel companies barely managed to cover the running costs and taxes, while credit indebtedness was prolonged. A large number of people were losing their jobs every day, and travel agencies were about to close. According to the National Association of Tourist Agencies of Serbia, unless some drastic measures are introduced, half of the people working in the tourism sector will lose their jobs. The state has introduced economic measures to help domestic businesses and to stabilize the economy ${ }^{27}$. Modern management is an expression of the multidisciplinary of science and practice. ${ }^{28}$

Fiscal measures, financial assistance, and liquidity measures were part of the package received by companies in the tourism sector. When it comes to fiscal measures, for workers working in small and medium enterprises in the tourism sector, the payment of taxes and contributions has been postponed, so that small and medium enterprises can repay those obligations in equal monthly instalments over the next two years. For tourism companies in the private sector, the state ensured the payment of the minimum wage for three months. It should be mentioned that workers in the tourism sector received a minimum wage only if they had a contract with a company or agency. Those who had a time contract (for example, tourist guides) did not receive financial assistance. Unfortunately, there are thousands of workers in this sector who have experienced this situation. Small and medium-sized tourism companies had two options on how to improve their liquidity, either by using funds from the Development Fund or through favourable loans from commercial banks.

Travel agencies had a big problem, in addition to cancelled reservations, and that is the insurance policy. As for the cancelled reservations for domestic tourists, the agencies proposed a solution that they can give their customers exchangeable vouchers for their arrangements, and the Government accepted that proposal. Most of the citizens who have paid for the summer vacation took vouchers, which meant that they could use the paid amount by the end of 2021,

$27 \quad$ Republic of Serbia, MTTT - Ministry of trade, tourism and telecommunications (2020): Notice on allocation of subsidies for support to the work of travel agencies of tourist travel organizers due to difficulties in business caused by the epidemic of the disease Covid 19, published on November $19^{\text {th }}$, Available at: https://mtt.gov.rs/vesti/obavestenje-o-dodelisubvenicja-za-podrsku-radu-turistickih-agencija/ (Accessed on 26.12.2020)

28 Rabrenović, Mihajlo, (2011): Strategijski menadžment u javnom sektoru. Službeni glasnik, Beograd, 26 
or they could ask for a refund from January 1 to 14, 2022. However, this was a short-term solution to the problem, because it is only a matter of postponing the obligations of travel agencies, which are to be fulfilled or return the money to customers by January 1,2022. The biggest problem of travel agencies in Serbia at this moment is not reflected in the fulfilment of their financial obligations, on the contrary, it is reflected on the ability if they can work at all. In the earlier period, we witnessed numerous frauds of travel agencies, after which passengers were left without travel and paid money. Few years ago, in order to prevent such a trend, the Government of the Republic of Serbia prescribed conditions under which it became possible to do business as a travel agency. Anyone who wanted to open a travel agency was obliged to provide bank guarantees that were at the level of 200 to 400 thousand euros. That way, the Government wanted to protect domestic and international tourists from possible frauds. However, as the Covid 19 virus pandemic began, travel agencies knew they would not be able to provide the necessary guarantees under the circumstances.

The existing insurance policies were valid until October 1,2020, and after that day, travel agencies could no longer perform their activities. The relevant Ministry of Trade, Tourism, and Telecommunications were also informed about everything. Without policies, agencies did not have the work permit. Insurance companies refused to insure travel agencies because of the high risk due to the Covid 19 virus pandemic and they also did not want to insure agency arrangements even under the condition of increasing the price of the policy. After October $1^{\text {st }}$ Travel agencies were left with the option to sell only individual services, tickets, or hotel accommodation because this is provided differently. Negotiations have been held with insurance companies to extend the validity of existing insurance policies for an additional three months in order to find an appropriate solution in the meantime. According to the current regulations, insurance policies can also be sold by the banks, but the conditions with the banks are much stricter and the premiums are more expensive. The line ministry, in agreement with the banks, tried to find an adequate solution to enable travel agencies to obtain a license. According to the Ministry, two insurance models for travel agencies were planned, one through bank guarantees and the other through insurance policies. In cooperation with the banks, the drafting of a rulebook that would regulate the issuance of bank guarantees was initiated.

It was planned that the insurance policies would last for a year. Also, insurance companies requested from travel agencies to show their business balance sheets, so that they could start the insurance process to begin with. The Association of Receptive Agencies - URA ${ }^{29}$, which brings together 25 receptive agencies, had about 4.5 thousand cancelled trips and arrangements worth about 1,055,000

29 The Association of Receptive Agencies - URA, (2020): Proposed measures to help tourism, Available in Serbian at: http://mladizaturizam.org.rs/predlog-mera-za-pomoc-turizmuudruzenja-receptivnih-agencija/ (Accessed on 29.12.2020). 
euros. To get a real impression of the damage caused, these figures should be increased by almost 40-50\%. Reception agencies have requested that mandatory deposits be temporarily abolished at the end of each month, for the entire period from the introduction of the state of emergency until the end of 2020 . Since all jobs were blocked for the agencies, it was necessary to keep as much money as possible in the accounts in order to save jobs and for the agencies to continue working. Once the regular situation is re-established, by bringing the virus pandemic under control, travel agencies together with partners from the hotel industry and catering will be able to quickly continue to perform their core business and receive new guests. The way receptive travel agencies work involves contracting with foreign tour operators to bring foreign guests to Serbia months in advance, which leads to the conclusion that these agencies will need the same amount of time to bring their business into a regular flow, and thus start receiving payments, and generate revenue.

Demand for foreign guests is expected to rise again, as well as for domestic ones, especially for rural tourism. What is frightening are the consequences that the Covid 19 virus pandemic has left on the economy and the additional poverty of citizens abroad, which could be reflected in a smaller need to travel due to the lack of money. The Association of Receptive Agencies presented concrete proposals to the Ministry of Trade, Tourism, and Telecommunications to improve working conditions in this sector, taking into account the fact that Serbia is still an attractive destination and interesting to many foreign agencies discovering new destinations and exploring new opportunities in the tourism market. Therefore, measure was proposed that would be applied in the next two years, so that all group stays of foreign guests in Serbia can be realized only with cooperation agreements or vouchers of domestic receptive agencies, which are registered in the Business Registers Agency, Tourism Register and Tourist associations by the end of 2019 at the latest. This is important as a part of the income is kept in the country so that it does not end up completely in foreign budgets. The biggest problem faced by receptive travel agencies is that before the pandemic they received money for certain travel arrangements, and a good part of that money was largely forwarded to other service providers as a guarantee for the arrival of tourist groups, and a part of that money remained on agency accounts. As it is unknown how long the virus pandemic crisis could last, the money was kept in liquidity reserves. However, foreign partners demanded a refund for trips that were not realized. On the other hand, service providers were not willing to return the money to receptive agencies, so agencies found themselves in a position to lose the trust of their foreign partners and lose jobs in the future. Another problem occurs with those agencies that have decided to return the money for unrealized trips because they have put themselves in a position that they do not have enough funds in the account for regular obligations to pay rent, utilities, and arrears, thus bringing themselves to the brink of bankruptcy. The circumstances led these agencies to carefully analyze 
the situation on the markets where their passengers mostly came from ${ }^{30}$, while expecting the state's help in resolving these existential issues, and to see when they could start the journey to Serbia again.

\section{Measures of the Government of the Republic of Serbia to assist travel agencies during the Covid 19 pandemic}

Travel agencies in Serbia have been waiting for a long time for the help of the state in overcoming business problems caused by the proclamation of the Covid 19 virus epidemic, which put them in an unenviable position, endangered their business, and put them on the brink of extinction. The general opinion is that the state did not react in time to help the tourism sector. All measures introduced at the beginning of the pandemic were temporary and limited to three months during the state of emergency. However, problems in the business of travel agencies continued during the summer tourist season in 2020, due to a new wave of the coronavirus that spread both in Serbia and the surrounding countries in the region. This led to the closure of the borders of some of the popular tourist destinations, which was also reflected in the travel agencies that had arrangements made at these destinations. Besides, the insurance policies of the agencies stood out, and the insurance agencies did not want to renew them due to excessive risks, and the state did not come out with concrete measures of assistance until the agencies officially lost the licenses to work from October 1. In mid November, the Government of Serbia adopted a rulebook on amendments to the terms and conditions of licensing travel organizers, as well as a rulebook on amendments to the rulebook on the type, amount, and conditions of travel guarantee, the number of deposits depending on the license category, activation, purpose of funds, as well as other conditions that must be met by the travel organizer ${ }^{31}$. These regulations came into force on November 14, 2020 $0^{32}$. The license is ranked in different categories depending on the number of passengers, for whom organized tourist trips have been sold in the previous 12 months, by the tour operators, counting from the day of submitting the request until issuing the license. The number of passengers includes the number of passengers from the sold tourist

Ibid.

31 Republic of Serbia, MTTT - Ministry of trade, tourism and telecommunications (2020): Notice on allocation of subsidies for support to the work of travel agencies of tourist travel organizers due to difficulties in business caused by the epidemic of the disease Covid 19, published on November $19^{\text {th }}$, Available at: https://mtt.gov.rs/vesti/obavestenje-o-dodelisubvenicja-za-podrsku-radu-turistickih-agencija/ (Accessed on 26.12.2020)

32 The Official Gazette of the Republic od Serbia, number 137/2020 - Regulation on amendments to the Regulation on the conditions and manner of ranking the travel organizer's license in different categories, the manner of changing the license category, the content of the request for issuance and renewal of the license, as well as the conditions and manner of issuing the ceremonial license form. 
trips, regardless of whether they were realized or not, as well as whether an offer for the use of a replacement trip was issued for them or a replacement trip was agreed. A new measure was the introduction of two lower license categories, A10 and A15, with a lower limit of travel guarantee coverage, as follows:

- category A10 license from 10 to 300 passengers, with a coverage limit of 50,000 euros;

- category A15 license from 301 to 600 passengers, with a coverage limit of 100,000 euros;

- category A20 license from 601 to 1000 passengers, with a coverage limit of 200,000 euros;

- category A25 license from 1001 to 5000 passengers, with a coverage limit of 250,000 euros;

- category A35 license from 5001 to 10000 passengers, with a coverage limit of 350,000 euros;

- category A40 license with over 10,000 passengers, with a coverage limit of 400,000 euros.

Also, the Government of Serbia met the requirements set by travel agencies and which referred to the reduction of the number of deposits, which the travel agency was obliged to have on the account on the last day of the current month:

- $\quad$ EUR 300 for a license ranked in category A10;

- EUR 500 for a license ranked in category A15;

- EUR 1,000 for a license ranked in category A20;

- EUR 1,500 for a license ranked in category A25;

- EUR 2,500 for a license ranked in category A35;

- $\quad$ EUR 3,500 for a license ranked in category A40.

The new regulations left the possibility for agencies to change the license to a lower category, which would have a significantly lower coverage limit, in which way, in greater numbers, they can conclude a travel guarantee contract with insurance companies or provide a bank guarantee. ${ }^{33}$

\section{Conclusion}

If trends of the Covid 19 virus pandemic continue, the Serbian tourism sector will need at least two to four years to recover. Although the Government has implemented various measures to protect this sector, it is obvious that this assis-

33 The Official Gazette of the Republic of Serbia, number 137/2020 - Regulation on amendments to the Regulation on the type, amount and conditions of the travel guarantee, the amount of the deposit depending on the license category, method of activation, purpose of funds, as well as other conditions that must be met by the travel organizer. 
tance will not be enough to protect and save all actors and companies in the tourism market. The Ministry of Trade, Tourism and Telecommunications is also trying to see how it can stimulate domestic tourist demand in the future and provide much-needed relief to all companies in this area, as Serbia relies solely on its own financial resources. Many of those who have worked in this sector were forced to find new jobs. Many companies in the tourism sector are either closed or something like that will follow in the near future. Unfortunately, there are limited resources and ways in which this sector can be helped. The only hope for this sector is for the pandemic to end soon and for the world to "go back to normal." Travel agencies are one of the biggest victims of the COVID-19 pandemic, which has made their business more difficult, and has reflected in the risk assessment and the amount of costs in the process of issuing travel guarantees. The competent ministry started to change the existing regulations in the direction of considering the real circumstances that arose as a consequence of the corona virus pandemic. Tourism, in order to function normally, needs open borders, as well as stable political, socio-economic and above all, health and safety conditions. It is clear that the current pandemic already has and will have extremely negative consequences for the tourism of Serbia, both in the terms of initiative and receptive movements. There is no doubt that the decline in tourist travel of Serbian citizens abroad will strongly affect domestic travel agencies, which mostly base their business on organizing the travel of domestic travellers to foreign destinations, especially for the purpose of vacation. Unlike tourist trips abroad, Serbian citizens who visit domestic tourist destinations use the services of agencies to a much lesser extent, and certainly the growth of domestic passenger movements is not a factor that would significantly affect the increase of economic benefits. What will be crucial for the business of receptive travel agencies in the future in Serbia are not only subjective factors such as public and private sector measures that include health and administrative measures, quality and promotion of the tourist offer, etc., but will play a crucial role objective factors to be implemented by countries that represent very important emitting areas of demand for Serbian travel agencies. The future of business of travel agencies in Serbia will depend on the health and economic-social conditions that will be implemented in those countries. 


\section{Literature}

- Abu Bakar, N., \& Rosbi, S. (2020). Effect of coronavirus disease (COVID-19) to tourism industry. International Journal of Advanced Engineering Research and Science (IJAERS). 2020; 7(4). Available at: https://dx.doi.org/10.22161/ ijaers.74.23, ISSN: 2349-6,189. (Accessed on 23.12.2020)

- Antonio, S. (2020), The Tourism Industry and the Impact of COVID 19: Scenario and Prospects, Global Journey Consulting, 2020.

- Brouder, P., Teoh, S., Salazar, N. B., Mostafanezhad, M., Pung, J. M., Lapointe, D., ... \& Clausen, H. B. (2020). Reflections and discussions: tourism matters in the new normal post COVID-19. Tourism Geographies, 1-12, Available at: https://doi.org/10.1080/14616688.2020.1770325 (Accessed on 24.12.2020).

- Chang, C.L., McAleer, M., \& Ramos, V. (2020). A Charter for Sustainable Tourism after COVID-19, Sustainability, 12(9), 3671 Available at: https://doi. org/10.3390/su12093671 (Accessed on 26.12.2020).

- Chinazzi, M., Davis, J. T., Ajelli, M., Gioannini, C., Litvinova, M., Merler, S., ... \& Viboud, C. (2020). The effect of travel restrictions on the spread of the 2019 novel coronavirus (COVID-19) outbreak. Science, 368(6489), 395-400, Available at: https://doi.org/10.1126/science.aba9757 (Accessed on 26.12.2020).

- Estevão, C., \& Costa, C. (2020). Natural disaster management in tourist destinations: a systematic literature review. European Journal of Tourism Research, 25, 2502, Available at: https://ejtr.vumk.eu/index.php/about/article/view/417 (Accessed on 29.12.2020.).

- Gössling, S., Hall, C.M., \& Scott, D., (2020). Pandemics, Tourism and Global Change: a Rapid Assessment of COVID-19. Journal of Sustainable Tourism, first published 27 April, Available at: https://doi.org/10.1080/09669582.2020.17 58708 (Accessed on 24.12.2020).

- Hall, C.M., Scott, D., \& Gössling, S. (2020). Pandemics, Transformations and Tourism: Be Careful What You Wish for. Tourism Geographies, first published 28 April, Available at: https://doi.org/10.1080/14616688.2020.1759131 (Accessed on 24.12.2020).

- Hoque, A., Shikha, F. A., Hasanat, M. W., Arif, I., \& Hamid, A. B. A. (2020). The effect of Coronavirus (COVID-19) in the tourism industry in China. Asian Journal of Multidisciplinary Studies, 3(1), 52-58. (Accessed on 26.12.2020).

- Jamal, T., \& Budke, C. (2020). Tourism in a world with pandemics: local-global responsibility and action. Journal of Tourism Futures, 6(2), 181-188, Available at: https://doi.org/10.1108/JTF-02-2020-0014 (Accessed on 24.12.2020).

- Luković, S., Stojković, D. (2020): Covid - 19 pandemic and global tourism, Hotel and Tourism Management 8 (2): 79 -87. doi: 10.5937/menhottur2002079L

- Ma, C., Rogers, J. H., \& Zhou, S. (2020). Modern Pandemics: Recession and Recovery (June 2020). Available at SSRN: https://ssrn.com/abstract=3565646 or http://dx.doi.org/10.2139/ssrn.3565646 (Accessed on 28.12.2020). 
- Matiza, T. (2020). Post-COVID-19 crisis travel behaviour: towards mitigating the effects of perceived risk. Journal of Tourism Futures. Available at: https:// doi.org/10.1108/JTF-04-2020-0063 (Accessed on 24.12.2020).

- McKinsey and Company. (2020). The future is not what it used to be: Thoughts on the shape of the next normal, Available at:https://www.mckinsey.com/featured-insights/leadership/the-future-is-not-what-it-used-to-be-thoughts-onthe-shape-of-the-next-normal\# (Accessed on 23.12.2020)

- Nepal, S. K., (2020). Travel and tourism after COVID-19 - business as usual or opportunity to reset? Tourism Geographies, 1470-1340. Available at: https:// doi.org/10.1080/14616688.2020.1760926 (Accessed on 24.12.2020).

- Rabrenović, Mihajlo. (2011). Strategijski menadžment u javnom sektoru. Službeni glasnik.

- Rabrenović, Mihajlo., Stošić, Sanja., \& Stamenović, Milorad. (2016). Značaj strategijskog upravljanja za klinička ispitivanja. Pravni život.

- Republic of Serbia, MTTT - Ministry of trade, tourism and telecommunications (2020). Notice on allocation of subsidies for support to the work of travel agencies of tourist travel organizers due to difficulties in business caused by the epidemic of the disease Covid 19, published on November $19^{\text {th }}$, Available at: https://mtt.gov.rs/vesti/obavestenje-o-dodeli-subvenicja-za-podrsku-raduturistickih-agencija/ (Accessed on 26.12.2020)

- Statistical Office of the Republic of Serbia (2020), Trends - III quarter 2020, Available at: https://publikacije.stat.gov.rs/G2020/pdf/G20208005.pdf (Accessed on 23.12.2020)

- Sumner, A., Hoy, C., \& Ortiz-Juarez, E. (2020) Estimates of the impact of COVID-19 on global poverty. WIDER Working Paper 2020/43. UNU-WIDER, Available at: https://doi.org/10.35188/UNU-WIDER/2020/800-9 (Accessed on 29.12.2020).

- The Association of Receptive Agencies - URA, (2020). Proposed measures to help tourism, Available in serbian at: http://mladizaturizam.org.rs/predlog-mera-za-pomoc-turizmu-udruzenja-receptivnih-agencija/(Accessed on 29.12.2020).

- The Official Gazette of the Republic od Serbia, number 137/2020 - Regulation on amendments to the Regulationg on the conditions and manner of ranking the travel organizer's license in different categories, the manner of changing the license category, the content of the request for issuance and renewal of the license, as well as the conditions and manner of issuing the ceremonial license form.

- The Official Gazette of the Republic od Serbia, number 137/2020 - Regulation on amendments to the Regulation on the type, amount and conditions of the travel guarantee, the amount of the deposit depending on the license category, method of activation, purpose of funds, as well as other conditions that must be met by the travel organizer. 
- UNWTO. (2020a). Impact assessment of the COVID-19 outbreak on international tourism, Updated December 2020, Available at: https://www.unwto. org/impact-assessment-of-the-covid-19-outbreak-on-international-tourism (Accessed on 24.12.2020)

- UNWTO. (2020b). Covid 19 Related Travel Restrictions, a Global Review for Tourism, First Report as of 16 April 2020. Madrid.

- WHO Coronavirus Disease (COVID-19) Dashboard, Available at: https:// covid19.who.int/ (Accessed on 02.01.2021).

- Yang, Y., Zhang, H., \& Chen, X. (2020). Coronavirus pandemic and tourism: Dynamic stochastic general equilibrium modeling of infectious disease outbreak. Annals of Tourism Research, 83, 102913 Available at: https://doi. org/10.1016/j.annals.2020.102913 (Accessed on 24.12.2020).

- Zenker, S., \& Kock, F. (2020). The coronavirus pandemic-A critical discussion of a tourism research agenda. Tourism Management, 81, 104164. Available at: https://doi.org/10.1016/j.tourman.2020.104164 (Accessed on 24.12.2020). 


\title{
POSLOVANJE TURISTIČKIH AGENCIJA U SRBIJI U VREME PANDEMIJE VIRUSA COVID 19
}

\begin{abstract}
Rezime: Cilj rada je da pokaže u kojoj meri su turističke agencije u Srbiji spremne da posluju u kriznim situacijama, poput trenutne izazvane pandemijom virusa Covid $19 i$ kakve posledice jedna ovakva pandemija može da ostavi na celokupnu turističku industriju jedne zemlje. Da bi se postigli ovi cijevi korišćeni su podaci iz različitih istraživanja sprovedenih tokom 2020. godine o uticaju pandemije Covid 19 na svetsku turističku industriju, kao i relevantni statistički podaci međunarodnih organizacija $i$ državnih institucija Republike Srbije. U radu se došlo do zaključka da su turističke agencije visoko zavisne od pomoći države, ali su i ti resursi ograničeni. Sva rešenja koja su predložena od strane Vlade republike Srbije oročena su do kraja 2021. godine do kada postoji nada da će virus oslabiti u čemu bi veliku ulogu trebalo da odigra i planirana vakcinacija stanovništva. Da bi turističke agencije u budućnosti mogle da nadvladaju situacije poput pandemije virusa potrebno je da rade na novim programima i na prilagođavanju novim ciljnim grupama i tržištima. Potrebno je otvoriti nove kanale prodaje, za slučaj nekih novih kriznih situacija kako bi agencije bile spremne i mogle da prežive date okolnosti.
\end{abstract}

Ključne reči: turističke agencije, Covid 19, kriza, turizam 